\title{
Effect of Step Pressure on Shape Forming of Alumina by Pressure-Vacuum Hybrid Slip Casting
}

\author{
Kyeong-Sik Cho ${ }^{\dagger}$, Hyun-Kwuon Lee, and Byeong-Joon Woo
}

School of Advanced Materials \& System Engineering, Kumoh National Institute of Technology, Gumi 730-701, Republic of Korea (Received February 12, 2013; Revised March 5, 2013; Accepted March 5, 2013)

\section{가압-진공 하이브리드 주입 성형에 의한 알루미나의 성형에 미치는 다단 가압의 영향}

\author{
조경식 ${ }^{\dagger}$ 이현권 · 우병준 \\ 금오공과대학교 신소재시스템공학부 \\ (2013년 2월 12일 접수 ; 2013년 3월 5일 수정 ; 2013년 3월 5일 채택)
}

\begin{abstract}
Conventional cold isostatic pressing, slip casting, and filter pressing are not completely suitable for fabricating large plates because of disadvantages such as the high cost of equipment and formation of density gradient. These problems could be avoided by employing pressure-vacuum hybrid slip casting (PVHSC). In the PVHSC, the consolidation occurs not only by the compression of the slip in casting room, but also by vacuum sucking of the dispersion medium around the mold. We prepared the alumina bodies by the PVHSC in a static- or stepwise-pressure manner for loading up to $0.5 \mathrm{MPa}$ using an aqueous slip. The green bodies were dried at $30^{\circ} \mathrm{C}$ with $40 \sim 80 \%$ relative humidity. Under static pressure, casting induced a density gradient in the formed body, resulting in cracking and distortion after the firing. However, the stepwise pressure loading resulted in green bodies with homogeneous density, and the minimization of the appearance of those defects in final products. Desirable drying results were obtained from the cast bodies dried with $80 \% \mathrm{RH}$ environment humidity. When sintered at $1650^{\circ} \mathrm{C}$ for $4 \mathrm{~h}$, the alumina plate made by stepwise-pressure casting reached full density ( $>99.7 \%$ relative density).
\end{abstract}

Key words: Alumina, Slip casting, Shape forming, Pressure slip casting, Vacuum slip casting

\section{1. 서 론}

알루미나는 기계적 강도뿐만 아니라 내열성, 내식성, 내 마모성 등이 우수하기 때문에 반도체 및 $\mathrm{LCD}$ 제조 장치 의 부재로 널리 사용되고 있는 소재이다. ${ }^{1,2}$ 반도체 및 $\mathrm{LCD}$ 부재를 제조하기 위한 세라믹 성형법에는 냉간 정 수압 성형(CIP, cold isostatic pressing), 슬립 주입 성형 (slip casting) 및 필터 프레스 성형(filter pressing)이 대표 적이다. CIP는 소재 생산업체에서 선호하는 성형 방법이 나, 넓은 면적의 대형 평판 소지를 제조하기 위한 장비 대형화가 용이하지 않다. 주입 성형 또한 저가의 공정비 용으로 인해 선호하는 성형법 이지만, 성형체의 두께를 증가 시키면 캐스팅 압력의 강하가 일어나 성형밀도 구

\footnotetext{
${ }^{\dagger}$ Corresponding author : Kyeong-Sik Cho

E-mail : kscho@kumoh.ac.kr

Tel : +82-54-478-7737 Fax : +82-54-478-7769
}

배를 일으키게 되어 건조, 소결의 후속 공정 중에 소지에 응력을 유발하여 휨이나 균열을 발생시키고 석고몰드를 빈번하게 교체해야 함으로 소재 안정성을 떨어뜨린다. 필 터 프레스 성형은 성형 틀 하부에 필터를 지지하고 그 위 에 슬립을 주입하고 피스톤으로 기계적으로 가압함으로 큰 성형압력을 이용하여 비교적 대형 기물을 성형할 수 있는 있는 방법이지만 밀도구배의 문제점은 여전히 가지 고 있다. ${ }^{3-5)}$

슬립 주입 성형에 대한 연구 중에는 석고 몰드의 0.1 $0.2 \mathrm{MPa}$ 의 낮은 모세관 흡입력에 추가하여 인공적 압력 을 가하거나, ${ }^{6,7)}$ 석고 몰드 대신에 필터를 이용하여 성형 시간을 단축한 보고가 있었다. ${ }^{8)}$ 필터 프레스 성형에서는 성형 시간 단축뿐만 아니라 균질한 성형체를 제조하기 위 한 연구도 보고되었는데, 기물이 대형일수록 중요한 요소 이다. 필터 프레스 성형 시, 자기장을 걸어주어 입자의 응 집을 유도하거나, ${ }^{9}$ 전기장을 걸어주어 입자들의 충전밀도 (packing density)를 높여, ${ }^{10)}$ 성형 균질성 향상을 꾀하였다. 
본 연구진은 가압 방식을 기계적 가압 대신 압축 공기를 이용하여 알루미나 슬립을 성형실로 주입함과 동시에 진 공펌프의 흡입으로 분산매가 고분자 멤브레인 필터를 통 해 배출되도록 설계한 가압-진공 하이브리드 주입 성형 (PVHSC, pressure-vacuum hybrid slip casting)을 고안 보 고하였다. ${ }^{11,12)}$

본 연구에서는 가압-진공 하이브리드 주입 성형에서 성 형체 밀도의 균질성을 향상시키기 위한 목적으로 슬립의 가압 방식을 변화시키며 알루미나 소지를 성형하였다. 상 업용 알루미나 분말을 원료로 수계 알루미나 슬립을 제 조하여 가압 주입 방식의 변화에 따른 가압-진공 하이브 리드 주입 성형 및 습도에 따른 건조가 알루미나 성형밀 도의 균질성에 미치는 영향을 비교 연구하였다.

\section{2. 실험 방법}

\section{1. 알루미나 슬립 제조}

가압-진공 하이브리드 주입 성형에 사용할 수계 알루미 나 슬립을 제조하기 위해 상업용 알루미나 분말(AES-11C, Sumitomo Chemical Co., Japan) $40 \mathrm{vol} \%$ 를 유기 첨가제 와 함께 분산매인 탈이온수(deionized water)에 혼합하 였다. 전체 고체 중에 첨가제의 종류와 함량은 분산제 로 $\mathrm{APC}\left(\right.$ Ammonium polycarbonate, $\left(\left(\mathrm{NH}_{4}\right)_{2} \mathrm{CO}_{3}\right)_{\mathrm{n}}, 40 \%$ liquid, specific gravity 1.15, San Nopco Korea Ltd., Korea) 0.6 wt\%, 가소제로 PEG-400(Polyethylene glycol, $\left(\mathrm{C}_{2} \mathrm{H}_{6} \mathrm{O}_{2}\right)_{\mathrm{n}}, \mathrm{MW}=$ $360 \sim 440$, Haian Guoli Chemical. Co., Ltd., China) $1.0 \mathrm{wt} \%$, 결합제로 PVA-205(Polyvinyl alcohol, $\left(\mathrm{CH}_{2} \mathrm{CHOH}\right)_{n}$, specific gravity 1.19-1.31, Kuraray Co., Ltd., Japan) $1.0 \mathrm{wt} \%$ 이었다.

플라스틱 용기(Nalgene bottle, Thermo Fisher Scientific Inc., USA)에 원료 혼합물과 분쇄매체로 $\mathrm{Al}_{2} \mathrm{O}_{3}$ 볼을 넣고 $150 \mathrm{rpm}$ 에서 6 시간 볼 밀링 하고, 소포제로 실리콘 emulsion(DB-110A, Dow Corning, USA)을 첨가하고 진공 교반 탈포 하여 가압-진공 하이브리드 주입성형용 알루미 나 슬립을 준비하였다. 수계 알루미나 슬립의 알루미나 입 자 크기 $\left(\mathrm{d}_{50}\right)$ 는 $0.43 \mu \mathrm{m}$ 이고 점도는 $175.8 \mathrm{cP}$ 이었다. ${ }^{12)}$

\section{2. 가압-진공 하이브리드 주입 성형}

Fig. 1에는 가압-진공 하이브리드 주입 성형 장치의 모 식도를 나타내었다. 가압-진공 하이브리드 주입 성형에 의 한 $110 \times 110 \times 20 \mathrm{~mm}$ 판상 알루미나 성형체 제조는 순차 적으로 다음과 같다. (1) 저장된 슬립은 압축공기에 의해 주입구를 통해 성형몰드 내부로 인입 된다. (2) 가압주입 으로 슬립의 알루미나 고체 분말은 성형몰드 내부에 충 전 성형된다. (3) 성형되고 나오는 분산매(물)는 성형몰드 외부에서의 진공흡입으로 $2 \mathrm{~mm}$ 직경 미세 홀이 있는 다 공질 PVC 지지대에 밀착되어 있는 멤브레인 필터(Polypropylene, Hwa Shin Special Textile Filter Co., Ltd. Korea)

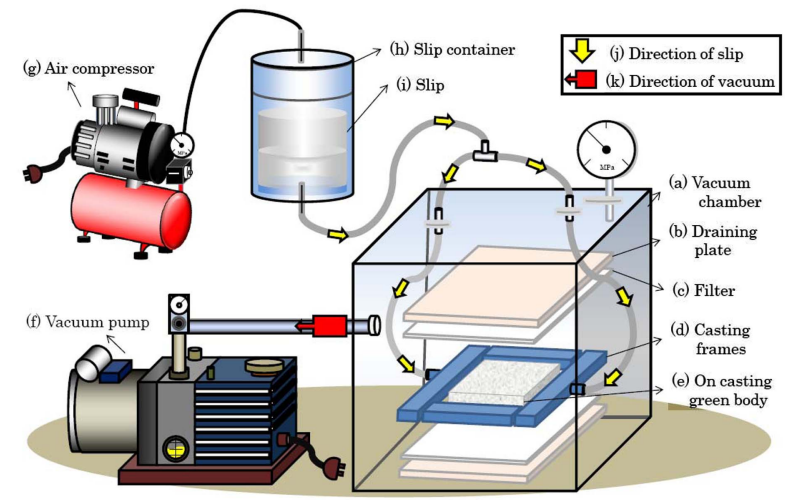

(a)

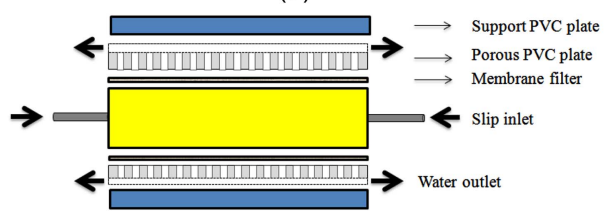

(b)

Fig. 1. Schematic diagrams of (a) pressure-vacuum hybrid slip casting(PVHSC) apparatus and (b) casting mold.

를 통하여 배출된다.

성형몰드로 공급되는 슬립에 가해지는 압축공기는 최 대 $0.5 \mathrm{MPa}$ 로 가압하는 가압 주입 성형과 성형몰드에서 배출되는 분산매의 진공흡입은 $0.05 \mathrm{MPa}$ 로 감압하는 진 공 주입 성형이 동시에 복합적으로 이루어지도록 하는 가 압-진공 하이브리드 주입 성형을 의도하였다. Fig. 2에서 와 같이 주입 압력을 가하는 방식은 처음부터 $0.5 \mathrm{MPa}$ 최 대압력으로 올려 5시간 유지하는 정압 주입 성형(constant pressure casting)과 낮은 압력 $(0.1 \mathrm{MPa})$ 부터 단계별로 최 대압력 $0.5 \mathrm{MPa}$ 까지 올려 5시간 유지하는 다단 가압 주 입 성형(step pressure casting)으로 구분하였다. 성형몰드 에 알루미나 슬립을 가압 주입하고 성형체 내부에 응력 을 줄이기 위해 천천히 상압까지 감압하였고, 진공흡입은 연장하여 성형을 종료하였다.

\section{3. 성형체 건조 및 소결}

알루미나 슬립으로부터 가압-진공 하이브리드 주입 성 형법으로 제조한 성형체는 온도와 습도를 정밀하게 조절 할 수 있는 건조장치에서 $30^{\circ} \mathrm{C}$ 온도를 유지하며 40,60 , $80 \% \mathrm{RH}$ 의 상대습도 조건으로 건조하였다.

슬립으로부터 출발하여 제조한 알루미나 성형체는 수 분과 유기물 결합제, 분산제, 가소제가 고체 분말과 함께 존재함으로 소결온도까지 승온 하는 과정에서 수분 증발 및 유기물 탈지를 고려해야 한다. ${ }^{13,14)}$ 따라서 PVHSC로 제작된 알루미나 성형체를 이와 같은 온도 구간을 고려 하며, ${ }^{12)} \mathrm{Fig}$. 3에서와 같은 스케줄에 의해 최고온도 $1650{ }^{\circ} \mathrm{C}$ 에서 4시간 유지하여 소결하고 로랭 하였다. 


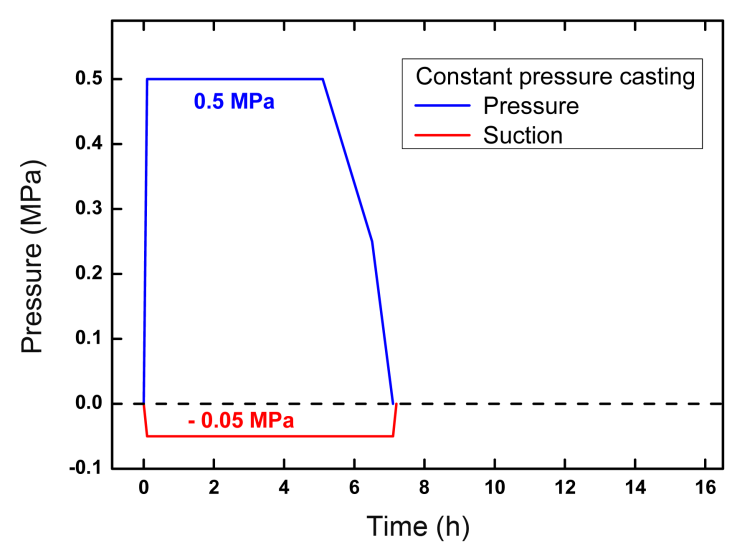

(a)

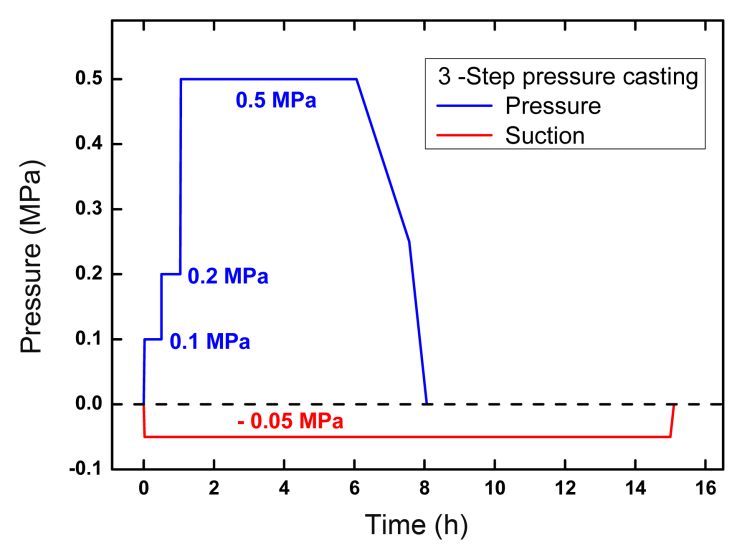

(b)

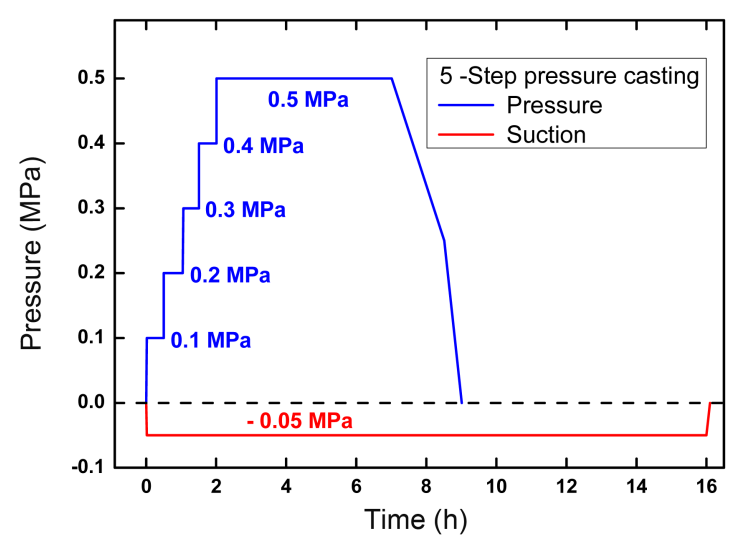

(c)

Fig. 2. Applied pressure schedules for the pressure-vacuum hybrid slip casting in (a) constant pressure casting, (b) 3-step pressure casting, and (c) 5-step pressure casting.

\section{4. 특성 분석}

가압-진공 하이브리드 주입 성형으로 제조한 성형체는 $100^{\circ} \mathrm{C}$ 에서 4 시간 동안 건조하여 부위별 성형밀도를 측정 하였다. 직경 $0.5 \mathrm{~mm}$ 줄을 이용한 정밀 줄톱을 이용하여 가로와 세로 방향으로 각각 5 등분, 두께 방향으로 3 등분

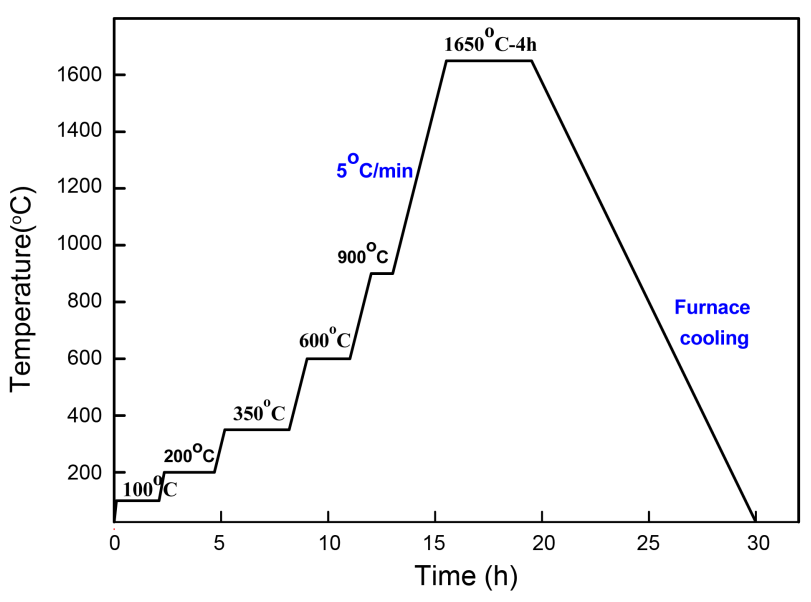

Fig. 3. Sintering schedule of the alumina formed body prepared by the pressure-vacuum hybrid slip casting.

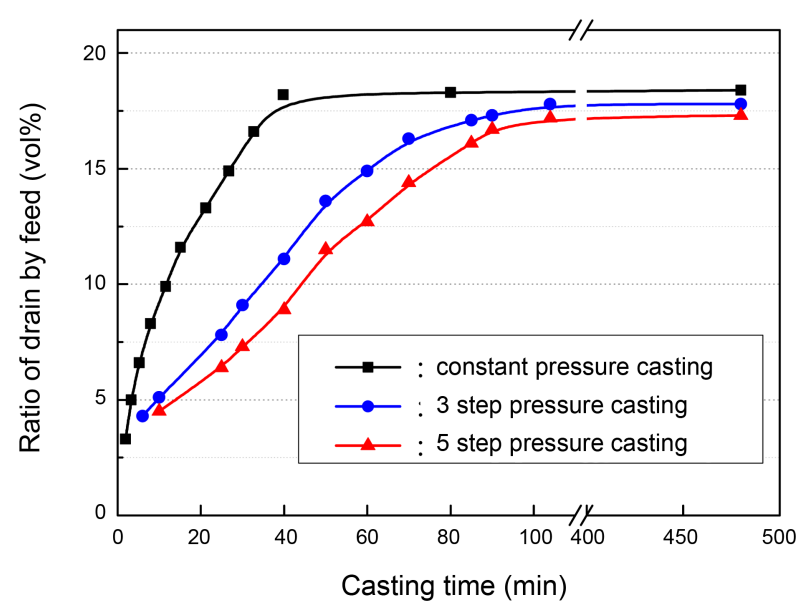

Fig. 4. The ratio of water drain by slip feed as a function of casting time for the pressure-vacuum hybrid slip casting in constant pressure casting and step pressure casting.

하고, 각 면을 $\mathrm{SiC}$ 연마포로 조심스럽게 연마하여 육면체 형상을 최대한 유지하게 하였다. 성형체 부위별로 전자저 울과 버니어켈리퍼스를 이용하여 겉보기 부피밀도를 구하 였고 FE-SEM(JSM-6500F, JEOL, Japan)으로 관찰하였다.

소결체는 Archimedes 원리에 의해 부피밀도를 측정 $(\mathrm{KS}$ L ISO 18754), 상대밀도를 구하였고, $0.2 \mu \mathrm{m}$ 다이아몬드 페이스트로 최종 연마하고 $1450^{\circ} \mathrm{C}$ 에서 열 에칭한 후 $\mathrm{FE}$ $\mathrm{SEM}$ 으로 미세구조를 관찰하였다.

\section{3. 결과 및 고찰}

\section{1. 가압-진공 하이브리드 주입 성형}

Fig. 4는 고체함량 $40 \mathrm{vol} \%$ 인 수계 알루미나 슬립을 가 압-진공 하이브리드 주입 성형 시, 정압 주입과 다단 가 압 주입에 대한 슬립의 주입 양에 대한 여과배출되는 물 
의 부피비를 시간 함수로 나타낸 주입배출 곡선의 그래 프이다.

성형 초기에는 주입배출 곡선의 기울기가 빠르게 증가 하다가, 성형이 진행됨에 따라 점진적으로 감소되어 기울 기가 평행을 이루어 일정하게 된다. 주입 슬립에 대한 배 출되는 물의 부피비인 주입배출 곡선의 기울기가 변동되 는 동안에는 슬립에 분산되어 있는 알루미나 분말이 성 형몰드 내에서 응집 착육 되어 성형이 진행되며, 이 기울 기가 일정하게 유지되면 대부분의 성형이 완성되는 것으 로 생각할 수 있다. 알루미나 슬립을 주입하는 압축공기 를 처음부터 최대압력으로 하는 정압 주입 성형에 비해 순차적으로 증가시키는 다단 가압 주입 성형이 초기 기 울기 증가속도가 느리다. 또한 주입배출 곡선의 기울기가 평형에 이르는 성형 완료시간은 정압 주입 성형에서는 약 40 분에 비하여, 3 단 가압 주입 성형에서는 2 배인 80 분이 고, 5 단 가압 주입성형에서는 약 120 분까지 성형이 진행 되는 것으로 판단된다.

\section{2. 성형체의 건조 특성}

Fig. 5는 가압-진공 하이브리드 주입 성형으로 제조한 알루미나 성형체를 건조 장치에서 $30^{\circ} \mathrm{C}$ 온도를 유지하며 $40,60,80 \mathrm{RH} \%$ 의 상대습도에서 건조하면서 성형체의 무 게를 일정시간 간격으로 측정하여 무게변화를 나타낸 그 래프이다.

주입 성형에 의해 제조된 성형체는 초기 수분함량 $15 \mathrm{wt} \%$ 정도이며 주입 성형체의 기공과 모세관에 수분을 함유하고 있으며 수분은 모두 연결된 상태이다. 건조공정이 시작되 면서 수분이 모세관력과 표면장력으로 표면 쪽으로 이동 하여 표면 층을 젖은 상태로 유지하기 때문에 일정한 속 도로 수분이 증발되는 정속 건조(constant drying rate)가 일어나며, 수분이 표면으로 이동함에 따라 입자들은 서로 압축되고 소지의 수축을 유발 시킨다. 시간이 지남에 따 라 내부에서 표면으로의 수분 공급이 불충분 하여 건조 속도가 차차 낮아지는 감속 건조(falling drying rate)로 전 환되며, 이미 입자들은 접촉하거나 달라 붙어있기 때문에 수축이 발생하지 않는다. ${ }^{15-17)}$ 일정시간이 지나면 기울기 가 0 으로 수렴되고 건조가 완료된다.

Fig. 5 에서 초기 건조 속도는 $80 \% \mathrm{RH}$ 분위기 초기 건조 곡선 기울기가 60 및 $40 \% \mathrm{RH}$ 분위기 경우보다 완만하여 건조한 분위기보다 높은 습도에서 건조하였을 때, 초기의 건조속도가 느린 것을 알 수 있다. 건조 완료까지 소요되 는 시간도 $80 \% \mathrm{RH}$ 에서의 성형체 건조완료 시간은 12 일 이상 $(298 \mathrm{~h}, 312 \mathrm{~h}$ 및 $304 \mathrm{~h})$ 으로 $40 \% \mathrm{RH}$ 에서의 건조 완료 시간 4 일 $(104 \mathrm{~h}, 109 \mathrm{~h}$ 및 $112 \mathrm{~h})$ 보다 약 3 배 길게 나타남 을 알 수 있었다. 또한 정압 주입보다 다단 가압 주입 성 형이 초기 건조속도가 느리고 완료시간도 길어짐을 알 수 있다.

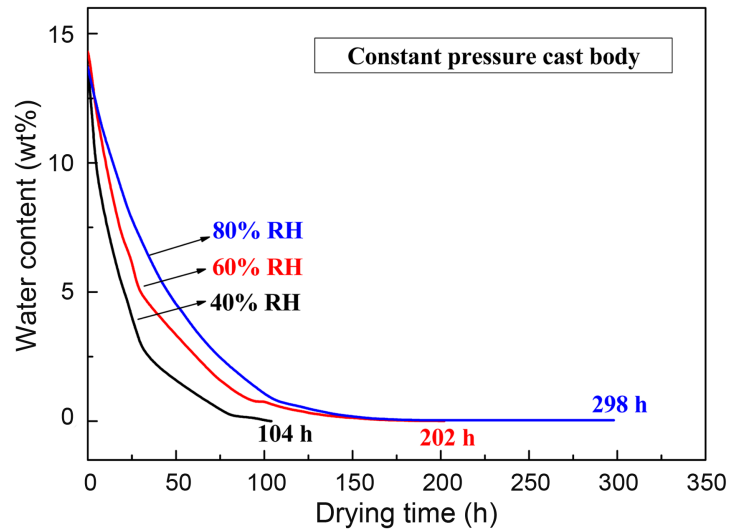

(a)

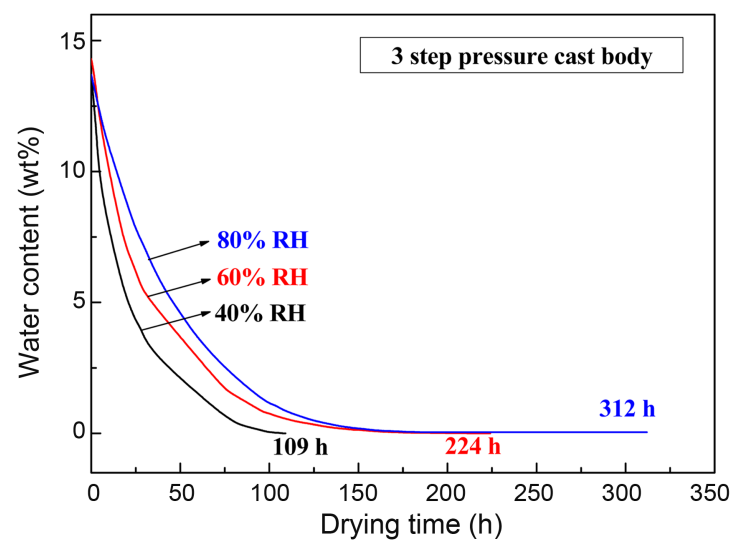

(b)

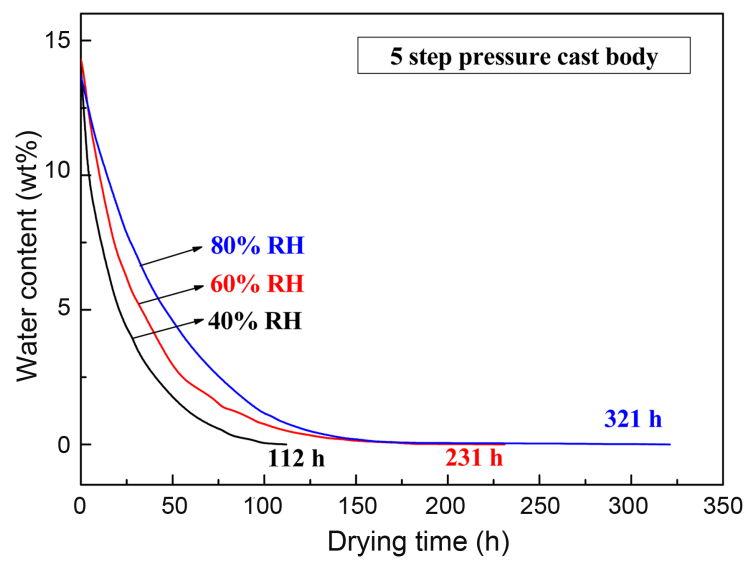

(c)

Fig. 5. Drying rates of alumina cast bodies by the pressurevacuum hybrid slip casting as a function of time with different humidity conditions for (a) constant pressure cast body (b) 3-step pressure cast body, and (c) 5-step pressure cast body.

약 $50 \%$ 의 밀도를 갖는 성형체의 건조속도가 빠르면 성 형체 표면이 내부보다 빠르게 건조 되어 표면수축이 내 부보다 빨리 진행되고 내부수축은 느리게 진행된다. 따라 서 내외부의 수축률 차이에 기인하여 표면에 인장응력이 
걸리게 되고 내부는 압축응력이 걸리게 된다. 이와 같은 응력이 발전하게 되면 성형체 표면에서부터 시작되는 균 열이 발생하기 때문에 일반적으로 건조속도를 느리게 하 는 것이 바람직하다고 알려져 있다. ${ }^{18-20)}$ 특히 두껍고 커 다란 형상의 세라믹스 성형체를 건조할 때는 온도 및 습 도의 조건을 적절하게 유지하여, 기물 외형의 변형이나 균열이 없도록 기물 부위별 수축률 차이에 의한 응력유 발을 최대한 억제하는 건조공정을 진행해야 한다.

\section{3. 성형체의 밀도구배}

Fig. 6은 가압-진공 하이브리드 주입 성형한 직후의 성형 체 사진들로 적절치 않은 조건으로 성형한 경우(Fig. 6(a) $\sim(\mathrm{d})$ )와 적절한 조건으로 성형한 경우(Fig. 6(e) (f))의 알루 미나 성형체이다. 성형시간이 충분치 않거나(Fig. 6(a)), 조 성이 적절치 못한 알루미나 슬립으로부터(Fig. 6(b)), 혹은 압축공기의 가압력이 약하거나(Fig. 6(c)) 진공흡입시간이 충분하지 않은(Fig. 6(b)) 조건으로 제조한 성형체는 외형 이 고르지 않았다. 적절한 조성의 알루미나 슬립으로부터 $0.5 \mathrm{MPa}$ 의 가압력으로 충분한 시간 동안 가압-진공 하이 브리드 주입 성형 시, 알루미나 성형체는 판상의 육면체 원 형을 유지하면서 성형몰드에서 쉽게 분리되고, Fig. 6(e) (f) 와 같이 멤브레인 필터 자국을 제외하고는 표면이 평활 하며 외형이 균질한 알루미나 성형체가 제조되었다.

Fig. 7에는 가압-진공 하이브리드 주입 성형으로 제조한 $110 \times 110 \times 20 \mathrm{~mm}$ 크기의 판상 알루미나 성형체를 75 등 분하여 부위별로 측정한 밀도 결과로 $45 \sim 60 \%$ 의 상대밀

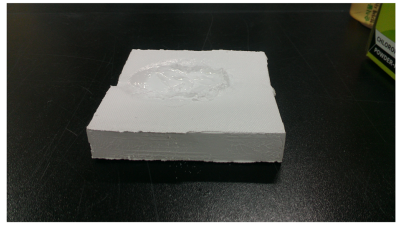

(a)

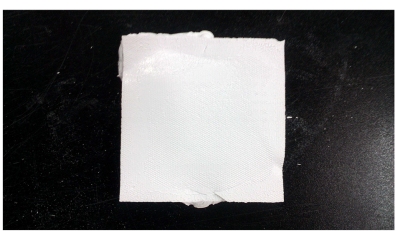

(c)

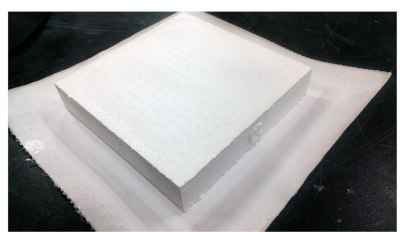

(e)

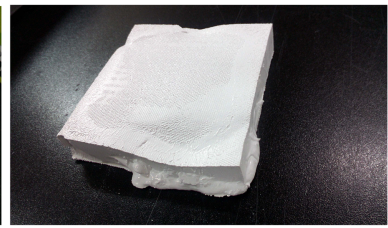

(b)

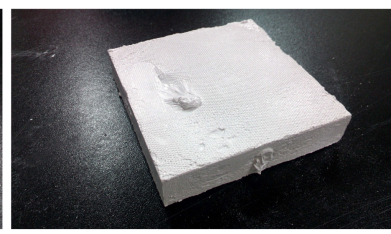

(d)

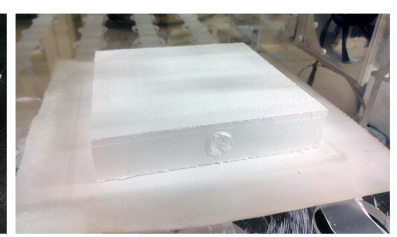

(f)
Fig. 6. Alumina green bodies prepared by the pressure-vacuum hybrid slip casting: (a), (b), (c), (d) failed green bodies, and well-formed green bodies prepared from (e) 3-step and (f) 5-step pressure casting.
도를 색깔로 구분하여 나타내었다. 이때의 시료는 가압진공 하이브리드 주입성형 장치에 의해 정압 주입 및 다 단 가압 주입으로 성형하고, $30^{\circ} \mathrm{C}, 80 \% \mathrm{RH}$ 조건에서 충 분히 건조하고 Fig. 7(a)와 같이 가로 세로 방향으로 각각 5 등분 및 두께 방향으로 3 등분 하여 준비하였다.

정압 주입 성형체는 Fig. 7(b)에서 보이는 바와 같이 가 장 자리는 상대적으로 높은 밀도분포로 최대 $56.9 \%$ 를 가 지며 중앙 부분이 상대적으로 낮고 최저 $47.4 \%$ 까지의 낮 은 성형밀도를 나타내고 있으며 부위별 상대밀도의 평균 은 $53.9 \%$ 이고 표준편차는 $2.0 \%$ 이다. 이는 주입 성형 되 는 초기에서부터 마지막까지 모든 부분의 성형체가 균일 한 압력을 받으며 형성되지 못한 결과로 생각되며, 윗부 분이 아랫부분보다 낮은 밀도는 슬립 내 고체의 자중에 의한 영향으로 생각된다. 성형체의 밀도가 부위별 최대 $9.5 \%$ 차이를 보이고 있으며, 이는 차후의 건조 및 소결 공 정에서 변형이나 균열을 유발시키는 치명적인 단점이 되 리라 예상된다.

다단 가압 주입 성형체는 Fig. 7(c)와 (d)에 보이는 바와 같이 정압 주입 성형체와 비교하여 전반적으로 고른 성 형 밀도분포이고, 부위별 상대밀도의 평균은 3 단 가압 주 입 성형체는 $54.4 \%$ 이고 5 단 가압 주입 성형체는 $57.9 \%$ 이 며, 표준편차는 각각 $1.7 \%$ 와 $0.8 \%$ 이다. 성형체 부위별로 성형 밀도의 구배가 발생되는 정압 주입 성형에 비해 슬 립의 주입 압력을 단계적으로 증가시키는 다단 가압 주 입 성형이 착육 속도는 느리지만 착육 층의 두께 성장에

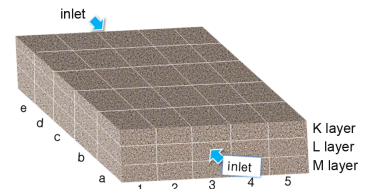

(a)

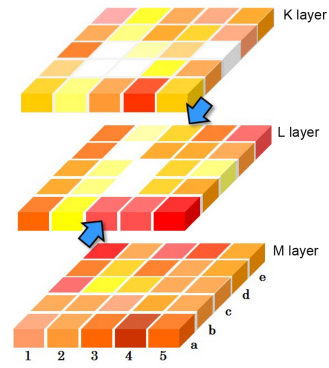

(c)

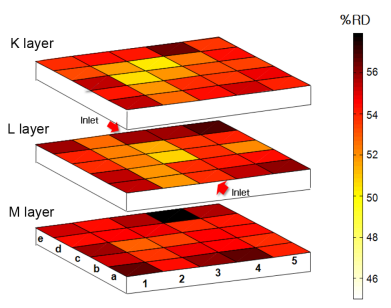

(b)

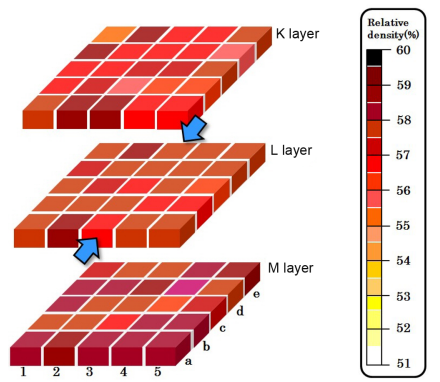

(d)
Fig. 7. Partial density distributions along the thickness of the alumina green bodies manufactured by the pressurevacuum hybrid slip casting: (a) each section of cast body and cast bodies fabricated by (b) constant pressure casting, (c) 3-step, and (d) 5-step pressure casting. 


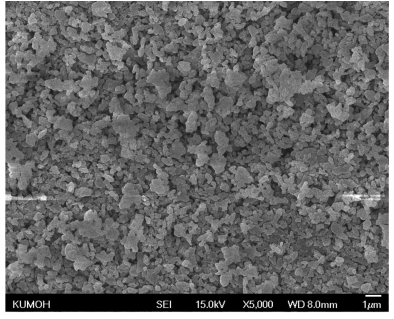

(a)

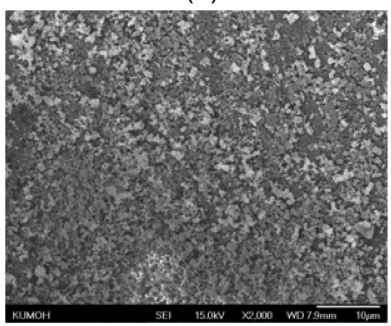

(a)

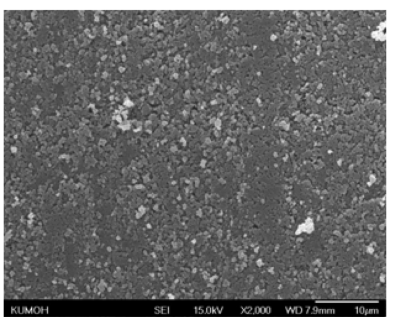

(a)

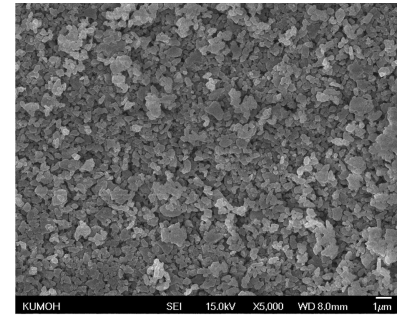

(b)

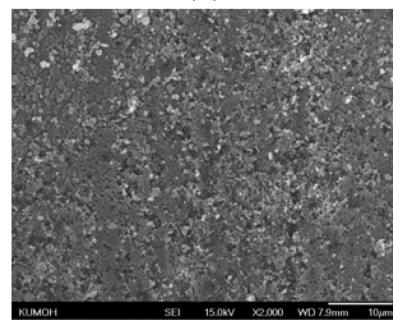

(b)

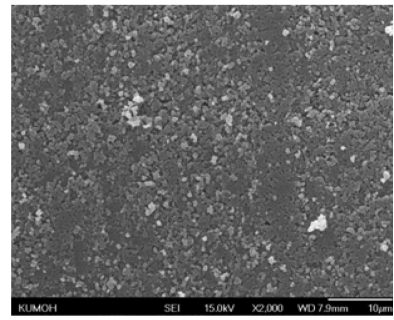

(b)
Fig. 8. SEM images of the top layer and inner parts for alumina formed bodies manufactured by the pressurevacuum hybrid slip casting in (a), (b) constant-, (c), (d) 3-step, and (e), (f) 5-step pressure casting.

따라서도 일정한 압력으로 일어나도록 유도하여 성형밀 도의 구배를 줄일 수 있었다고 판단된다.

Fig. 8은 가압-진공 하이브리드 주입 성형하여 제조한 성형체의 부위별 미세구조이다. 정압 주입 성형체와 다단 가압 주입 성형체를 관찰하였는데, 부위별로 유사한 미세 구조를 보이고 있다.

\section{4. 성형체의 소결성}

가압-진공 하이브리드 주입 성형 장치로 $110 \times 110 \times 20 \mathrm{~mm}$ 크기로 다단 가압 주입으로 성형하고 $30^{\circ} \mathrm{C}-80 \% \mathrm{RH}$ 에서 충 분히 건조하여 $1650^{\circ} \mathrm{C}$ 에서 소결하여 균열 없고 상대밀도 $>99.7 \%$ 로 치밀화 된 알루미나 소결체를 만들 수 있었다. 정압 주입으로 성형하고 동일한 조건으로 소결한 경우는 균열이 발생하였다. 균열 및 형상 변형이 생기는 원인은 성형, 건조, 탈지, 소결의 공정 전반에 걸쳐 불균일한 밀 도 및 응력 분포에 기인하는데, 주입의 압력구배에 따른 성형체 충전의 불균질에 의한 밀도구배 및 차후 가열에 따른 부위별 서로 다른 수축률 때문이다. ${ }^{21,22)}$

Fig. 9는 3단 및 5단 가압-진공 하이브리드 주입성형 하 여 제조한 알루미나 소결체를 상부 $(\mathrm{a}, \mathrm{d})$, 내부 $(\mathrm{b}, \mathrm{e})$ 및 하

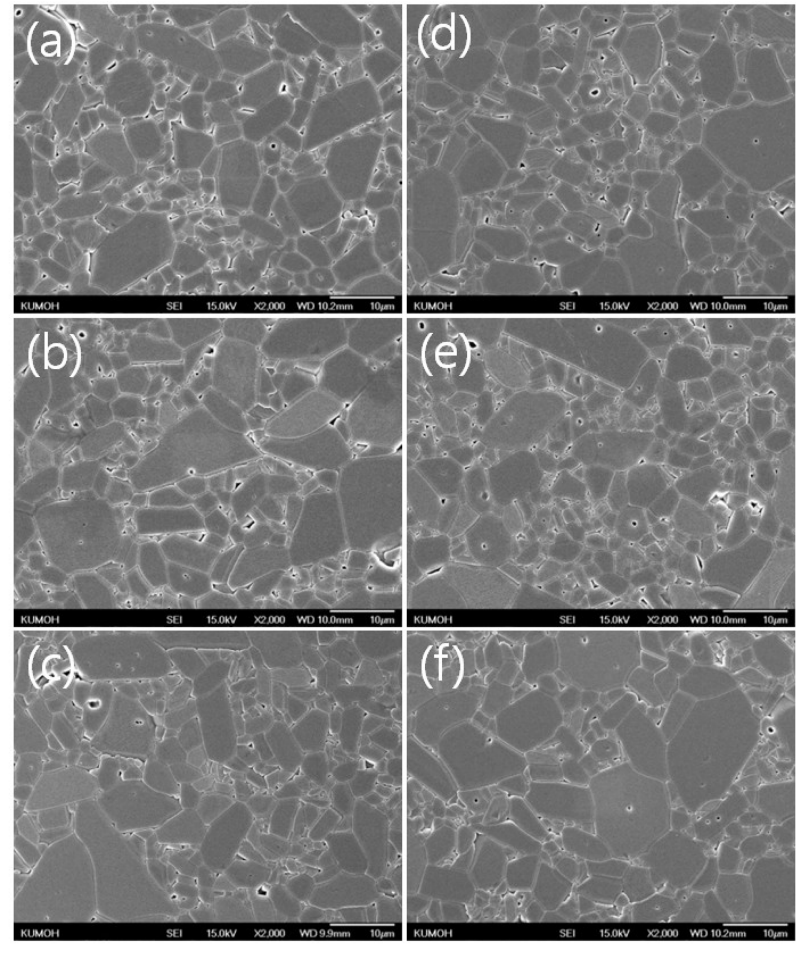

Fig. 9. SEM microstructures of each layer for alumina bodies sintered at $1650^{\circ} \mathrm{C}$ : $(\mathrm{a}, \mathrm{d})$ top, $(\mathrm{b}, \mathrm{e})$ inner, and (c, f) bottom layers manufactured by the pressure-vacuum hybrid slip casting in 3 step- and 5 step pressure casting, respectively.

부 지점(c, f)을 나누어 관찰한 미세구조이다. 전체적으로 $2 \sim 10 \mu \mathrm{m}$ 의 등축상 결정립으로 구성되어 있으며 입계 기 공과 입내 기공도 포함되어 있는 전형적인 알루미나의 미 세구조를 나타내고 부위별 차이를 나타내지 않고 있다.

\section{4. 결 론}

평균크기 $0.43 \mu \mathrm{m}$ 의 알루미나 분말 $40 \mathrm{vol} \%, 175.8 \mathrm{cP}$ 점도의 수계 알루미나 슬립을 압축 공기로 성형실로 주 입함과 동시에 여과필터를 통해 분산매를 진공 흡입하는 가압-진공 하이브리드 주입 성형(pressure-vacuum hybrid slip casting)하여 $110 \times 110 \times 20 \mathrm{~mm}$ 크기의 알루미나를 성 형체를 제조하는 경우, 정압 가압 주입과 다단 가압 주입 방법에 따른 비교 연구에서 다음과 같은 결론을 얻었다.

1. 최대 압력 $0.5 \mathrm{MP}$ 의 가압과 $0.05 \mathrm{MPa}$ 로 진공흡입 배 출하는 가압-진공 하이브리드 주입 성형 시, 주입압력을 일정하게 가하는 정압 주입 성형(constant pressure casting) 에 비해 낮은 압력부터 단계별로 최대압력까지 올리는 다 단 가압 성형(step pressure casting)이 성형시간에 따른 주 입배출 곡선의 초기의 기울기가 완만하게 증가하고 일정 하게 평형상태에 이르는 성형 완료 시점이 길어진다. 
2. 정압 주입 성형에 비해 다단 주입 성형한 경우가 성 형밀도가 높고 부위별 밀도분포가 균질하며, 건조 시 상 대습도가 높을수록 성형 밀도분포가 상대적으로 균일하였다.

3. 고체함량 $40 \mathrm{vol} \%$, 분산제 $0.4 \%$ 의 수계 알루미나 슬 립으로부터 다단 가압 주입의 가압-진공 하이브리드 주입 성형 하고 $1650^{\circ} \mathrm{C}$ 에서 4 시간 소결하여 균열 없고 $>99.7 \%$ 로 치밀화된 알루미나 소결체를 제조하였다.

\section{Acknowledgment}

본 연구는 금오공과대학교학술연구비에 의하여 연구된 논문으로 이에 감사 드립니다.

\section{REFERENCES}

1. H. K. Lee, K.-S. Cho, M. H. Jang, C. W. Jang, S. M. Kim, and M. Y. Kim, "Characteristics of Large Green and Sintered Alumina Ceramics by Filter Pressing(in Korean)," J. Kor. Ceram. Soc., 46 [3] 306-12 (2009).

2. K. Masaki, N. Hisao, and K. Yuraka, "Large-Sized Alumina Products for Next Generation LCD (Liquid Crystal Display) Manufacturing(in Jpn)," Shinagawa Technical Report, 48 139-40 (2005).

3. J. S. Reed, Principles of Ceramics Processing, pp. 492-524, 2nd ed., Wiley Interscience, New York (1995).

4. A. Kell and P. Blank, "The Influence of Shaping Method on the Grain Size Dependence of Strength in Dense Submicrometer Alumina," J. Eur. Ceram. Soc., 16 1189-200 (1996).

5. S. Blackburn and D. Ian Wilson, "Shaping Ceramics by Plastic Processing," J. Eur. Ceram. Soc., 28 1341-51 (2008).

6. A. Salomoni, I. Stamenkovic, S. M. Castanho, and R. Moreno, "Pressure Filtration of $\mathrm{Si}_{3} \mathrm{~N}_{4}$," J. Eur. Ceram. Soc., 17 267-71 (1997).

7. E. G. Blanchard, "Pressure Casting Improves Productivity," Am. Ceram. Soc. Bull., 67 [10] 1680-83 (1988).

8. T. Uchikoshi, Y. Sakka, K. Ozawa, and K. Hiraga, "Pressure Filtration and Sintering of Fine Zirconia Powder," J. Eur. Ceram. Soc., 18 669-74 (1998).

9. K. Kendall and M. R. Kosseva, "Nanoparticle Aggregation Influenced by Magnetic Fields," Coll. Surf. A: Physicochem.
Eng. Asp., 286 112-16 (2006).

10. K. Matsushima, Y. Hirata, N. Matsunaga, and S. Sameshima, "Pressure Filtration of Alumina Suspensions under Alternating Current Field," Coll. Surf. A: Physicochem. Eng. Asp., 364 138-44 (2010).

11. K.-S. Cho, J. Kim, S. Y. Lee, J. P. Oh, and S. I. Park, "Shape Forming of Alumina by Step Pressure-Vacuum Hybrid Slip Casting," Appl. Mech. Mater, 217-219 1899-902 (2012).

12. K.-S. Cho, I.-B. Song, and J. Kim, "Homogeneous Shape Forming of Alumina by Pressure-Vacuum Hybrid Slip Casting," J. Kor. Ceram. Soc., 49 [6] 592-600 (2012).

13. S. Wang, Q. H. Wang, X. L. Yang, L. Y. Wang, and H. S. Zhu, "Properties of Silk Fibroin/Poly(ethylene glycol) 400 Blend Films," Chinese J. Polymer Sci., 21 [1] 87-91 (2003).

14. J. Bozi, Z. Czegeny, E. Meszaros, and M. Blazso, "Thermal Decomposition of Flame Retarded Polycarbonates," J. Anal. Appl. Pyrolysis, 79 337-45 (2007).

15. G. Tari and J. M. F. Ferreira, "Influence of Solid Loading on Drying-Shrinkage Behaviour of Slip Cast Bodies," J. Eur. Ceram. Soc., 18 [5] 487 (1998).

16. G. W. Scherer, "Theory of Drying," J. Am. Ceram. Soc., 73 [1] 3-14 (1990).

17. W. -C. J. Wei and C. L. Hsieh, "Drying Kinetics of Ultrafine Alumina Cake with Drying Control Chemical (DCC)," $J$. Ceram. Soc. Jpn., 107 [4] 313-17 (1999).

18. J. D. Yates and S. J. Lombardo, "Effect of Solids Loading and Dispersant Concentration on Strain Mismatch and Deformation of Slip-Cast Green Bodies," J. Am. Ceram. Soc., 84 [10] 2274-80 (2001).

19. J. D. Yates and S. J. Lombardo, "The Effect of Plaster Composition and Binder Concentration on Strain Mismatch and Deformation of Slip-cast Green Bodies," Mater. Sci. Eng., A337 297-305 (2002).

20. J. L. Amoros, E. Sanchez, V. Cantavella, and J. C. Jarque, "Evolution of the Mechanical Strength of Industrially Dried Ceramic Tiles during Storage," J. Eur. Ceram. Soc., 23 [11] 1839-45 (2003).

21. S. W. Kim, H. W. Lee, H. S. Song, and B. H. Kim, "Pore Structure Evolution During Solvent Extraction and Wicking," Ceram. Inter., 22 7-14 (1996).

22. S. W. Kim, H. W. Lee, and H. S. Song, "Effect of Minor Binder on Capillary Structure Evolution During Wicking," Ceram. Inter, 25 671-76 (1999). 